\title{
Characterization of Nitrobenzylthioinosine Binding to Nucleoside Transport Sites Selective for Adenosine in Rat Brain ${ }^{1}$
}

\author{
J. D. GEIGER, ${ }^{* 2}$ F. S. LABELLA, ${ }^{\star}$ AND J. I. Nagy‡ \\ *Department of Pharmacology and Therapeutics and $\ddagger$ Department of Physiology, University of Manitoba, Faculty of Medicine, \\ Winnipeg, Manitoba R3E OW3 Canada
}

\begin{abstract}
Nucleoside transport sites in rat brain membrane preparations were labeled with $\left[{ }^{3} \mathrm{H}\right]$ nitrobenzylthioinosine $\left(\left[^{3} \mathrm{H}\right]\right.$ NBI), a potent inhibitor of nucleoside transport systems. The membranes contained a single class of very high affinity binding sites with $K_{D}$ and $B_{\max }$ values of $0.06 \mathrm{~nm}$ and $147 \mathrm{fmol} /$ $\mathrm{mg}$ of protein, respectively. The displacement of $\left[{ }^{3} \mathrm{H}\right] \mathrm{NBI}$ binding by various nucleosides, adenosine receptor agonists and antagonists, and known nucleoside transport inhibitors was examined. The $K$, values (micromolar concentration) of $\left[{ }^{3} \mathrm{H}\right] \mathrm{NBI}$ displacement by the nucleosides tested were: adenosine, 3.0; inosine, 160; thymidine, 240; uridine, 390; guanosine, 460; and cytidine, 1000. These nucleosides displayed parallel displacement curves indicating their interaction with a common site labeled by $\left[{ }^{3} \mathrm{H}\right] \mathrm{NBI}$. The nucleobases, hypo$x$ anthine and adenine, exhibited $K$, values of 220 and 3640 $\mu \mathrm{M}$, respectlvely. Adenosine receptor agonists exhibited moderate affinities for the $\left[^{3} \mathrm{H}\right] \mathrm{NBI}$ site, whereas the adenosine receptor antagonists, caffeine, theophylline, and enprofylline, were ineffective displacers. The $K_{\text {, values for cyclo- }}$ hexyladenosine, (+)- and (-)-phenylisopropyladenosine, 2chloroadenosine, and adenosine 5 '-ethylcarboxamide were $0.8,0.9,2.6,12$, and $54 \mu \mathrm{M}$, respectively. These affinities and the rank order of potencies indicate that $\left[{ }^{3} \mathrm{H}\right] \mathrm{NBI}$ does not label any known class of adenosine receptors (i.e., $A_{1}, A_{2}$, and $P$ ). The $K_{i}$ values of other nucleoside transport inhibitors were: nitrobenzylthioguanosine, $0.05 \mathrm{~nm}$; dipyridamole, 16 nM; papaverine, $3 \mu \mathrm{M}$; and 2'-deoxyadenosine, $22 \mu \mathrm{M}$. These results indicate that $\left.{ }^{3} \mathrm{H}\right] \mathrm{NBI}$ binds to a nucleoside transporter in brain which specifically recognizes adenosine as its preferred endogenous substrate. This ligand may aid in the identification of CNS neural systems that selectively accumulate adenosine and thereby control "adenosinergic" function.
\end{abstract}

Received June 4, 1984; Revised August 31, 1984;

Accepted August 31, 1984

\footnotetext{
'This work was supported by grants from the Health Sciences Centre Research Foundation to J. D. G. and J. I. N., the Manitoba Mental Health Research Foundation and the University of Manitoba Faculty Fund to J. I. N., and the Medical Research Council of Canada to F. S. L. J. D. G. is a Fellow of the Manitoba Health Research Council; J. I. N. is a Scholar of the Medical Research Council of Canada; and F. S. L. is a Career Investigator of the Medical Research Council of Canada.

${ }^{2}$ To whom correspondence should be addressed, at Department of Pharmacology and Therapeutics, University of Manitoba, Faculty of Medicine, 770 Bannatyne Avenue, Winnipeg, Manitoba R3E OW3, Canada.
}

The biochemical characterization and cellular location of sites involved in transporting biologically active substances across cytoplasmic membranes have been greatly facilitated by the use of radioligands which bind to these sites. Ligands which label neurotransmitter uptake sites have been especially useful for identifying neuronal systems releasing particular transmitters. The identification of neuronal uptake sites that contribute to terminating the transmitter actions of, for example, norepinephrine, serotonin, and glutamic acid has been achieved using $\left[{ }^{3} \mathrm{H}\right]$ desipramine (Lee et al., 1982), $\left[{ }^{3} \mathrm{H}\right]$ imipramine (Langer et al., 1980), and $\left.{ }^{3} \mathrm{H}\right]$ glutamic acid (Fonnum, 1984), respectively. Recently, the binding of $\left[{ }^{3} \mathrm{H}\right]$ nitrobenzylthioinosine $\left(\left[{ }^{3} \mathrm{H}\right] \mathrm{NBI}\right)$, a very potent nucleoside transport inhibitor to guinea pig (Hammond and Clanachan, 1983) and rat (Marangos et al., 1982b; Wu and Phillis, 1982) brain membrane preparations, was examined and it was proposed that $\left[{ }^{3} \mathrm{H}\right] \mathrm{NBI}$ labels adenosine uptake sites (Marangos et al., 1982b). The presence of these sites in brain tissue could be of considerable significance with respect to the putative CNS transmitter role of adenosine (Phillis and Wu, 1981), and $\left[{ }^{3} \mathrm{H}\right] \mathrm{NBI}$ may be a valuable marker for determining this role. Other indicators of the functional role of adenosine in the CNS include the association of specific high affinity adenosine receptors in brain and spinal cord with specific neural systems (Goodman and Snyder, 1982; Goodman et al., 1983; Wojcik and Neff, 1983; Geiger et al., 1984a, b); the existence of high affinity neuronal uptake mechanisms for adenosine (Bender et al., 1980, 1981; Thampy and Barnes, 1983a); depolarization-induced, calcium-dependent adenosine release (Stone, 1981); the selective distribution of $5^{\prime}$-nucleotidase, the enzyme responsible for formation of adenosine from $5^{\prime}$ adenosine monophosphate (Schubert et al., 1979); and the discrete localization of neurons in the CNS containing adenosine deaminase, a major degradative enzyme for adenosine (Nagy et al., 1984).

The utility of $\left[{ }^{3} \mathrm{H}\right] \mathrm{NBI}$ as a marker for adenosine uptake sites where adenosine may have its relevant actions depends, of course, on its selectivity. That $\left.{ }^{3} \mathrm{H}\right] \mathrm{NBI}$ labels functional nucleoside transport systems in the periphery appears well established (Plagemann and Wohlhueter, 1980; Paterson et al., 1981; Young and Jarvis, 1983). As a rule, $\left[{ }^{3} \mathrm{H}\right] \mathrm{NBI}$ binding has been identified only on cells that have functional nucleoside transport sites. Cass et al. (1974) found that occupancy of transport sites by NBI correlated with the decreased transport of nucleosides and that the density of functional transport sites correlates on a sites per cell basis with the transport system's maximal velocity $\left(V_{\text {max }}\right)$. This has been shown for erythrocytes from sheep (Jarvis et al., 1982), fetal lambs (Jarvis and Young, 1982), and humans (Cass et al., 1974); guinea pig and rat heart preparations (Williams et al., 1984), HeLa cells (Dahlig-Harley et al., 1981); and an adenosine-resistant clone $\left(\mathrm{AE}_{1}\right)$ of $\mathrm{S} 49$ lymphoma cells (Cass et al., 1981).

The nature of the nucleoside transport system labeled by $\left[{ }^{3} \mathrm{H}\right] \mathrm{NB} \mid$ in brain, however, is less clear. For example, the concentration of $\mathrm{NBI}$ necessary to inhibit adenosine uptake (transport plus metabolism) into rat and guinea pig cortical synaptosomes was found to be 
approximately 3 to 4 orders of magnitude greater than the $K_{i}$ value for displacing $\left[{ }^{3} \mathrm{H}\right] \mathrm{NBI}$ from synaptosomal membranes (Wu and Phillis, 1982; Phillis and Wu, 1983). Moreover, displacement studies using the adenosine transport inhibitors, dipyridamole and dilazep, yielded biphasic curves, indicating an interaction with more than one class of binding sites (Hammond and Clanachan, 1984). As there appear to be some important and potentially significant differences between the CNS and peripheral nucleoside transporters labeled by $\left[{ }^{3} \mathrm{H}\right] \mathrm{NBI}$ (Marangos et al., 1982b; Wu and Phillis. 1982), we reexamined the binding characteristics of this ligand to rat brain membranes. Here, we confirm and extend the observations that $\left[{ }^{3} \mathrm{H}\right]$ $\mathrm{NBI}$ labels a nucleoside transport system in rat brain that specifically and selectively recognizes adenosine as the preferred endogenous substrate. Thesc results have implications for the role of rapid reuptake mechanisms for terminating the actions of adenosine.

\section{Materials and Methods}

Tissue preparation. Fresh whole brains, excluding the brainstem and cerebellum, were obtained from adult male Sprague-Dawley rats sacrificed by decapitation. The brains were quickly excised, weighed, and placed into $10 \mathrm{vol}$ of ice-cold Tris- $\mathrm{HCl}$ buffer $(50 \mathrm{~mm}, \mathrm{pH} 7.4)$. The tissue was homogenized using a Polytron set at medium speed for $15 \mathrm{sec}$, centrifuged for 10 min, at 35,000 $\times g$, resuspended in Tris buffer, and centrifuged as above. This final pellet was resuspended in Tris buffer to a final concentration of 1.5 to $2.0 \mathrm{mg}$ of protein/ml. Protein was determined in aliquots of this firlal suspension by the method of Lowry et al. (1951) using bovine serum albumin as standard.

$\left[{ }^{3} \mathrm{H}\right] \mathrm{NBI}$ binding assay. $\left[{ }^{3} \mathrm{H}\right] \mathrm{NB}$ binding site saturation studies were conducted in a total volume of $1 \mathrm{ml}$ of Tris buffer containing 0.025 to $2.5 \mathrm{nM}$ $\left[{ }^{3} \mathrm{H}\right] \mathrm{NBI}(16.1 \mathrm{Ci} / \mathrm{mmol}), 150$ to $200 \mu \mathrm{g}$ of membrane protein in the absence or presence of $5 \mu \mathrm{M}$ unlabeled NBI. Specific displaceable $\left[{ }^{3} \mathrm{H}\right] \mathrm{NBI}$ binding was determined by subtracting nonspecific binding (presence of $\mathrm{NBI}$ ) from total $\left[{ }^{3} \mathrm{H}\right] \mathrm{NB}$ l binding (absence of NBI) values obtained from assays performed in duplicate. In a typical experiment using $0.6 \mathrm{~nm}\left[{ }^{3} \mathrm{H}\right] \mathrm{NBI}$, the values for total and nonspecific binding were 2,188 and $375 \mathrm{cpm} / \mathrm{mg}$ of protein, respectively. Similar values for nonspecific binding were obtained using 5 $\mu \mathrm{M}$ of either nitrobenzylthioguanosine (NBG) or dipyridamole. The potencies for various compounds displacing $\left[^{3} \mathrm{H}\right] \mathrm{NB}(0.6 \mathrm{nM})$ were calculated from data plotted on semi-log graphs. The displacing concentrations used for NBI, NBG, and dipyridamole ranged from 0.05 to $10,000 \mathrm{nM}$, and those for all other compounds tested ranged from 1.0 to $10,000 \mu \mathrm{M}$. The samples were incubated tor $15 \mathrm{~min}$ at $24^{\circ} \mathrm{C}$ and the reactions were terminated by rapid filtration through Whatman GF/B filters under reduced pressure. The filters were subsequently washed quickly with $3 \mathrm{ml}$, followed by a single $10-\mathrm{ml}$ wash, of ice-cold Tris buffer. The filters were placed in scintillation vials, and $10 \mathrm{ml}$ of ACS scintillation fluid (Amersham) were added; following at least a 6-hr interval, the filters were counted in a Beckman LS8100 scintillation counter at $38 \%$ efficiency. The nonlinear, multipurpose curve-fitting program LIGAND (Munson and Rodbard, 1980) was used to determine dissociation constant $\left(K_{D}\right)$ and maxima! number of binding sites $\left(B_{\text {rlax }}\right)$ values from the saturation data. The $\mathrm{IC}_{50}$ values were calculated as that amount of displacer necessary to inhibit the specific displaceable binding of $\left[{ }^{3} \mathrm{H}\right] \mathrm{NB}$ by $50 \% . K_{i}$ values were subsequently determined according to the Cheng and Prusoff (1973) equation, $K_{j}=I_{50} /\left(1+L / K_{D}\right)$, where $K_{D}$ is the dissociation constant for $\left[{ }^{3} \mathrm{H}\right] \mathrm{NBI}$ binding. $L$ represents the concentration of $\left[{ }^{3} \mathrm{H}\right] \mathrm{NB}$ l used in the displacement study, and $\mathrm{IC}_{50}$ is the calculated value for the particutar displacer compound.

Materials. The following chemicals were obtained from Research Biochemicals Inc. (Wayland, MA): $N^{6}$-cyclohexyladenosine, and $(-)$ - and $(+)-N^{6}$. phenylisopropyladenosine. $2^{\prime}$-Deoxyadenosine was purchased from $\mathrm{P}$-L Biochemicals (Milwaukee, WI), and $\left[{ }^{3} \mathrm{H}\right]$ nitrobenzyl-6-thioinosine was from Moravek Biochemicals inc. (Brea, CA). 2'-Deoxycoformycin (Pentostatin), adenosine $5^{\prime}$-ethylcarboxamide, and enprofylline were kindly supplied by Dr. L. Klienman, National Cancer Institute (Silver Spring, MD), Dr. E. L. Waroch, Abbott Laboratories (Chicago, IL), and Dr. C. G. A. Persson, AB Draco (Lund, Sweden), respectively. All other chemicals were obtained from Sigma Chemical Co. (St. Louis, MO)

\section{Results}

A representative $\left[{ }^{3} \mathrm{H}\right] \mathrm{NBI}$ saturation binding study using freshly prepared brain membrane preparations is illustrated in Figure 1. The isotherm indicates that the binding sites were saturated under the conditions employed. Iterative nonlinear analysis of the data (inset to Fig. 1) demonstrated a single class of very high affinity sites with a $K_{D}$ of $0.06 \mathrm{nM}$ and a $B_{\max }$ of $147 \mathrm{fmol} / \mathrm{mg}$ of protein. The same values were obtained whether the incubations were at $4^{\circ} \mathrm{C}(45 \mathrm{~min})$, $24^{\circ} \mathrm{C}(15 \mathrm{~min})$, or $37^{\circ} \mathrm{C}(10 \mathrm{~min})$.

The maximum binding of $\left[{ }^{3} \mathrm{H}\right] \mathrm{NBI}$ to membranes from rat brain was reached within the first 2 min of incubation at $24^{\circ} \mathrm{C}$. However, our assays were routinely incubated for $15 \mathrm{~min}$ to ensure the attainment of equilibrium and optimal levels of binding. The rapidity of the binding and reports in the literature on the use of NBI as a photoaffinity probe (Marangos et al., 1982a; Shi et al., 1984) led us to examine, as a precautionary measure for subsequent displacement studies, the effects of light on the binding process. When NBI $(0.05$ to $10,000 \mathrm{~nm})$ was used to displace $0.6 \mathrm{nM}\left[{ }^{3} \mathrm{H}\right] \mathrm{NBI}$ from rat brain membrane preparations incubated either in the dark or ex posed to 65 lux fluorescent lighting, the displacement curves were identical, giving $K_{i}$ values of $0.05 \mathrm{~nm}$ (data not shown). $\left[{ }^{3} \mathrm{H}\right] \mathrm{NBI}$ binding was similarly unaffected by changing the $\mathrm{pH}$ of the incubation media from 6.0 to 9.0 . The effects of endogenous adenosine depletion on $\left[{ }^{3} \mathrm{H}\right] \mathrm{NB} \mid$ binding was assessed by preincubating the tissue with 1.0 international unit of adenosine deaminase (Sigma, type $\mathrm{VII}$ ) for $30 \mathrm{~min}$ at $37^{\circ} \mathrm{C}$, centrifuging the membrane preparation, resuspending the pellet in Tris butfer, and conducting NBI displacement studies. This procedure has previously been shown to eliminate the influence of endogenous adenosine on the binding of radioligands to adenosine receptors. No differences in the $K_{i}$ values for $\mathrm{NBI}$ were observed between the two different tissue preparations (data not included)

The very high affinity of this ligand for the transport sites necessitated calculation of both $\mathbb{I C}_{50}$ and $K_{i}$ values. With a $K_{0}$ of $0.06 \mathrm{nM}$ and the need to use $0.6 \mathrm{nM}\left[{ }^{3} \mathrm{H}\right] \mathrm{NBI}$ for the displacement studies to give an adequate signal, the $\mathrm{IC}_{50}$ values for unlabeled competitors would be shifted approximately one order of magnitude to the right on a semi-log plot of the data. For example, the $1 C_{50}$ value for $\mathrm{NBI}$ displacing $0.6 \mathrm{nM}\left[{ }^{3} \mathrm{H}\right] \mathrm{NBI}$ was approximately $0.6 \mathrm{~nm}$, whereas this $\mathrm{IC}_{50}$ value, recalculated in terms of $K_{i}(0.05 \mathrm{nM})$, was similar to the $K_{D}(0.06 \mathrm{nM})$ of $\left[{ }^{3} \mathrm{H}\right] \mathrm{NBI}$ binding.

The results from displacement sludies for the nucleosides and nucleobases tested are illustrated in Figure 2, and the $\mathrm{IC}_{50}$ and $K_{i}$ values are listed in Table I. Adenosine, which inhibited the binding of $\left[{ }^{3} \mathrm{H}\right] \mathrm{NBI}$ with a $K_{i}$ of $3.0 \mu \mathrm{M}$, was 55 times more potent than inosine, the nucleoside next in potency. Thymidine, uridine, guanosine, and cytidine were, respectively, $82,130,155$, and 333 times less potent than adenosine. The nucleobases, hypoxanthine and adenine, also displaced $\left.{ }^{3} \mathrm{H}\right] \mathrm{NBI}$. However, although hypoxanthine exhibited a displacing potency comparable to some nucleosides, the competition curves for both nucleobases were non-parallel with that of adenosine.

To determine the extent of $\left[{ }^{3} \mathrm{H}\right] \mathrm{NBI}$ interaction with adenosine receptors, various adenosine receptor agonists and antagonists were tested; the displacement curves are shown in Figure 3. The adenosine receptor agonists cyclohexyladenosine $(\mathrm{CHA}),(+)$ - and $(-)$-phenylisopropyladenosine (PIA), 2-chloroadenosine, and adenosine 5 '-ethylcarboxamide (NECA) all inhibited the binding of $\left[{ }^{3} \mathrm{H}\right]$ $\mathrm{NB}$ I with parallel displacement curves. At a concentration of $1 \mathrm{~mm}$, the adenosine antagonists caffeine and enprofylline did not affect $\left[{ }^{3} \mathrm{H}\right] \mathrm{NB}$ l binding, whereas theophylline reduced specific binding by only $12 \%$. At similar concentrations various adenine and guanine nucleotides failed to compete for $\left[{ }^{3} \mathrm{H}\right] \mathrm{NBI}$ binding sites. The nucleoside transport inhibitors NBI and NBG were equipotent, whereas dipyridamole and the opiate derivative, papaverine, were less potent in competing for $\left[{ }^{3} \mathrm{H}\right] \mathrm{NBI}$ binding sites (Table I).

\section{Discussion}

The present investigation was designed to address the issue of whether $\left[{ }^{3} \mathrm{H}\right] \mathrm{NB}$ l binds to nucleoside transport sites having as broad a nucleoside substrate specificity in rat brain as that reported for peripheral tissues (Cass et al., 1981; Dahlig-Harley et al., 1981; Williams et al., 1984), or labels adenosine uptake sites as suggested 


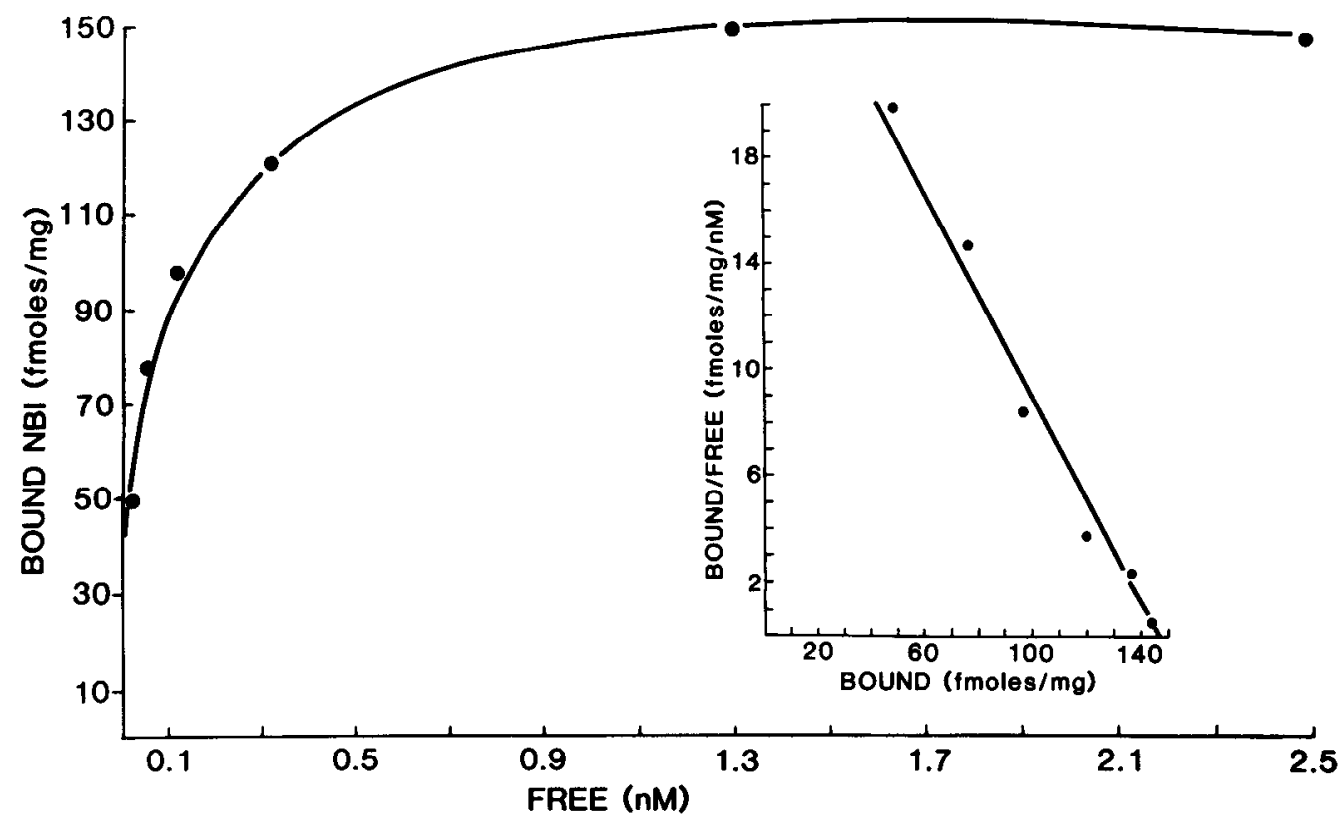

Figure 1. Saturation analysis of $\left[{ }^{3} \mathrm{H}\right] \mathrm{NBI}$ binding to membrane preparations of rat brain. Specific [ $\left.{ }^{3} \mathrm{H}\right] \mathrm{NBI}$ binding to membranes from whole rat brain (minus the cerebellum and brainstem) is illustrated as the saturation isotherm and Scatchard plot (inset). $\left[{ }^{3} \mathrm{H}\right] \mathrm{NBI}$ binding in the presence of $5 \mu \mathrm{M} \mathrm{NBI}$ (nonspecific binding) was subtracted from total binding values (absence of unlabeled $\mathrm{NB}$ ) to determine levels of spccific displaceable binding. All assays were performed in duplicate, and this figure is representative of similar experiments conducted five times. The $K_{D}$ and $B_{\max }$ values were derived from computer analysis of the data according to the program LIGAND (Munson and Rodbard, 1980). A single class of high affinity binding sites was observed with values for $K_{D}$ and $B_{\max }$ of $0.06 \mathrm{~nm}$ and $147 \mathrm{fmol} / \mathrm{mg}$ of protein, respectively.

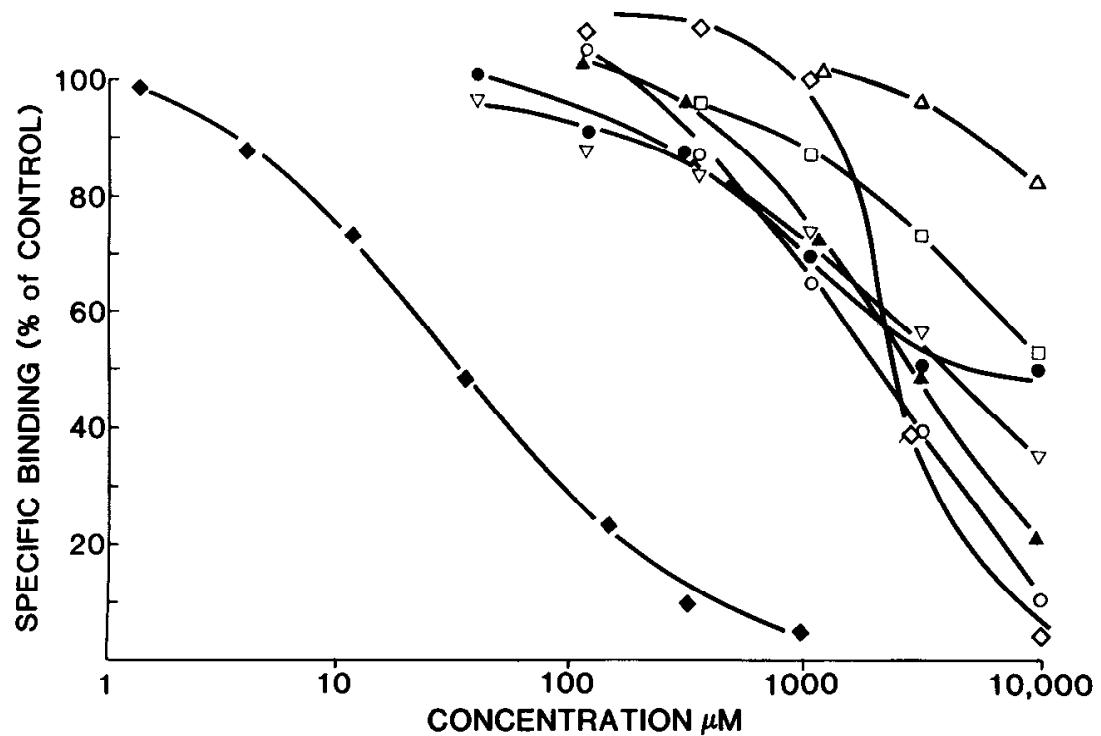

Figure 2. Displacement of $\left[{ }^{3} \mathrm{H}\right] \mathrm{NBI}$ binding to mem branes from rat brain by various nucleosides and nucleobases. $I_{50}$ values for adenosine $(\bullet)$, inosine $(O)$, thymidine $(\boldsymbol{\Delta})$, uridine $(\nabla)$, guanosine $(\Theta)$, cytidine $(\square)$, hypoxanthine $(\diamond)$, and adenine $(\Delta)$ were determined using $0.6 \mathrm{nM}\left[{ }^{3} \mathrm{H}\right]$ $\mathrm{NBl}$ and 8 to 10 concentrations of the displacers. Control binding values represent the amount of $\left[{ }^{3} \mathrm{H}\right] \mathrm{NBI}$ binding displaceable by $5 \mu \mathrm{M} \mathrm{NBI}$. These results are representative of experiments performed in duplicate and conducted at least twice with similar results. Note the parallel nature of the displacement curves for the nucleosides and not the nucleobases.

by Marangos et al. (1982b). This issue requires a close examination of information available on nucleoside transporters in peripheral and CNS tissues. Nucleoside transport is a facilitated diffusion system, which, at least in cultured cells, can transport a variety of nucleosides. However, certain methodological problems have been encountered in attempts to fully characterize this apparently simple carrier-mediated transport system. These include the high turnover rate of the nucleoside transporter; the non-concentrative nature of the system which limits the "measurable signal;" the confounding of results by intracellular metabolism, since the $K_{m}$ values of, for example, adenosine transport and adenosine kinase are similar, and the "awkward" mathematical modelling of the system (Wohlhueter et al., 1979). Bender et al. (1981), for example, found that, within 1 min, adenosine metabolites represented approximately $50 \%$ of the $\left[{ }^{3} \mathrm{H}\right]$ adenosine accumulated by rat brain synaptosomes. Under more controlled conditions, Thampy and Barnes (1983a), using ATP. depleted primary cultures of neurons derived from chick embryo brain, found that incubation times of 5 to $25 \mathrm{sec}$ were required to limit metabolism of newly accumulated $\left[{ }^{3} \mathrm{H}\right]$ adenosine to less than $1 \%$. Thus, it is not surprising that the measurement of nucleoside transport in CNS tissue has been difficult and the available data subject to different interpretations. This, then, provides the impetus for defining a radioligand binding system which can be used in identifying and characterizing such systems.

$\mathrm{NBI}$ reportedly binds to functional nucleoside transport sites in erythrocytes from various species (Cass et al., 1974; Jarvis and Young, 1982; Jarvis et al., 1982), cultured cells (Cass et al., 1981; Dahlig-Harley et al., 1981), and heart preparations (Williams et al., 1984). That $\mathrm{NBI}$ interacts with nucleoside transporters is further supported by the close correlation between $K_{i}$ values for compounds that inhibit $\left[{ }^{3} \mathrm{H}\right] \mathrm{NBI}$ binding and transport of nucleosides. Furthermore, NBI decreases the transport of uridine in intact human erythrocytes as a direct consequence of binding site occupation (Cass et al., 1974). Thus, it is clear from the literature that $\left[{ }^{3} \mathrm{H}\right] \mathrm{NBI}$ binding sites are only found in tissues which possess functional nucleoside transporters. However, it is uncertain whether NBI binds to the substrate recognition site, a closely related site (an allosteric modifier) (Young and Jarvis, 1983), or whether more than one type of nucleoside transporter exists (Paterson et al., 1981). These uncertainties may be particularly important when considering differences between central and peripheral nucleoside transport systems.

In the present study, $\left[{ }^{3} \mathrm{H}\right] \mathrm{NBI}$ bound with very high affinity to a single class of binding sites in rat brain membrane preparations with $K_{D}$ and $B_{\max }$ values of $0.06 \mathrm{~nm}$ and $147 \mathrm{fmol} / \mathrm{mg}$ of protein, respec- 
TABLE I

$I_{50}$ and $K_{i}$ values of various compounds for displacement of $\left[{ }^{3} \mathrm{H}\right] \mathrm{NBI}$ binding to rat brain preparations

Values represent means of experiments performed in duplicate (graphically represented in Figs. 2 and 3 ) and replicated with similar results. The $K_{i}$ values were calculated using the Cheng and Prusoff (1973) equation $\left(K_{\mathrm{i}}=1 \mathrm{IC}_{50} / 1+\right.$ $\left.L / K_{D}\right)$ where $L$ represents the concentration of $\left[{ }^{3} \mathrm{H}\right] \mathrm{NBI}$ used $(0.6 \mathrm{nM})$ and $K_{D}$ is the equilibrium dissociation constant for $\left[{ }^{3} \mathrm{H}\right] \mathrm{NBI}$ binding to rat brain membrane preparations $(0.06 \mathrm{nM})$. The following compounds at up to $1 \mathrm{mM}$ had no effect on $\left[{ }^{3} \mathrm{H}\right] \mathrm{NB}$ binding: GMP, GDP, GTP, AMP, ADP, ATP, CAMP, dibutyryl cAMP, 2-deoxycoformycin, caffeine, and enprofylline. Binding of $\left[{ }^{3} \mathrm{H}\right] \mathrm{NBI}$ was inhibited $12 \%$ by $1 \mathrm{~mm}$ theophylline.

\begin{tabular}{lcc}
\multicolumn{1}{c}{ Displacer } & \multicolumn{1}{c}{$\mathrm{K}_{50}$ Values } & \multicolumn{1}{c}{$K_{i}$ Values } \\
\hline Nucleosides and Nucleobases $(\mu \mathrm{M})$ & & \\
Adenosine & 33 & 3.0 \\
Inosine & 1,800 & 160 \\
Thymidine & 2,700 & 240 \\
Uridine & 4,300 & 390 \\
Guanosine & 5,100 & 460 \\
Cytidine & 11,000 & 1,000 \\
Hypoxanthine & 2,400 & 218 \\
Adenine & 40,000 & 3,640 \\
Adenosinc Analogues $(\mu \mathrm{M})$ & & \\
CHA & & \\
(+)-PIA & 8.8 & 0.8 \\
(-)-PIA & 10.2 & 0.9 \\
2-Chloroadenosine & 29 & 2.6 \\
NECA & 135 & 12.0 \\
Other Inhibitors (nM) & 590 & 54 \\
NBI & & \\
NBG & 0.56 & 0.05 \\
Dipyridamole & 0.56 & 0.05 \\
Papaverine & 175 & 16.0 \\
2'-Deoxyadenosine & 33,000 & 3,000 \\
& 245,000 & 22,000 \\
\hline
\end{tabular}

tively. These values are very similar to the $K_{D}(0.05 \mathrm{nM})$ and $B_{\max }$ (113 fmol/mg of protein) values reported by Wu and Phillis (1982). However, these workers also observed a lower affinity site with $K_{D}$ and $B_{\max }$ values of approximately $190 \mu \mathrm{M}$ and $1 \mathrm{nmol} / \mathrm{mg}$ of protein, respectively. We did not observe a second class of $\left[{ }^{3} \mathrm{H}\right] \mathrm{NBI}$ binding sites in any of our studies. A single class of $\left[{ }^{3} \mathrm{H}\right] \mathrm{NB}$ binding sites has been reported in brain membrane preparations from the rat with a $K_{D}$ of $0.18 \mathrm{nM}$ and $B_{\max }$ of $135 \mathrm{fmol} / \mathrm{mg}$ of protein (Marangos et al., $1982 \mathrm{~b}$ ) and from the guinea pig with $K_{D}$ values of 0.15 to 0.38 $\mathrm{nM}$ and $B_{\max }$ values of 201 to $644 \mathrm{fmol} / \mathrm{mg}$ of protein (Hammond and Clanachan, 1983).

In the present displacement studies, parallel inhibition curves were found for all compounds represented in Figures 1 and 2 except for the nucleobases, adenine and hypoxanthine. These nonparallel interactions indicate reactivity with sites labeled by $\left[{ }^{3} \mathrm{H}\right] \mathrm{NBI}$ but are dissimilar to those which recognize the other nucleosides, adenosine analogues and transport inhibitors. Interestingly, Cornford and Oldendorf (1975) reported the presence of two independent transport systems in tissues associated with the blood-brain barrier in rat: one for the nucleobases adenine and hypoxanthine, and the second for the nucleosides adenosine, guanosine, inosine, and uridine. We confirmed that NBI and NBG were the most potent inhibitors of $\left[{ }^{3} \mathrm{H}\right]$ NBI binding (see Table I). The structurally dissimilar, yet effective, nucleoside transport inhibitors, dipyridamole and papaverine, were also reasonably potent in displacing $\left[{ }^{3} \mathrm{H}\right] \mathrm{NBI}$ binding. In comparison with our $K_{i}$ values (Table I), the $K_{i}$ values (nanomolar concentration) recalculated from $I_{50}$ values given by Marangos et al. (1982b) for $\mathrm{NBI}, \mathrm{NBG}$, dipyridamole, and adenosine were: $0.23,1.3,283$, and 33,333 , respectively. The latter three compounds were approximately 10 to 30 times less potent than in our study. The reasons for these discrepancies are unclear.

Measurements of both nucleoside transport and $\left[{ }^{3} \mathrm{H}\right] \mathrm{NBI}$ binding indicate that certain important differences may exist between neuronal and non-reuronal nucleoside uptake systems. The reported $K_{m}$ values for adenosine uptake (transport plus metabolism) into various tissues were as follows: cultured astrocytes, $3.4 \mu \mathrm{M}$ (Hertz, 1978); cholinergic synaptosomes from Torpedo electric organ, 2.4 $\mu \mathrm{M}$ (Meunier and Morel, 1978); and rat brain synaptosomes, $1.0 \mu \mathrm{M}$ (Bender et al., 1980, 1981). In the uptake studies by Thampy and Barnes (1983a, b), which largely excluded metabolism secondary to transport, the $K_{m}$ value for adenosine uptake into primary cultures of neurons from chick embryo brain was $13 \mu \mathrm{M}$ and that in primary cultures of glial cells of similar origin was found to be of much lower affinity, $370 \mu \mathrm{m}$. Neuronal nucleoside transporters not only have higher affinity for adenosine but, when compared to other cell types, exhibit greater selectivity for adenosine relative to other nucleosides. The $K_{i}$ values for the inhibition of adenosine transport into neuronal cell cultures was $23 \mu \mathrm{M}$ for adenosine and was in the range of 300 to $1000 \mu \mathrm{M}$ for inosine, thymidine, and guanosine (Thampy and Barnes, 1983a). Corresponding values for inhibition of adenosine uptake into rat brain synaptosomes were $1.0 \mu \mathrm{M}$ for adenosine and

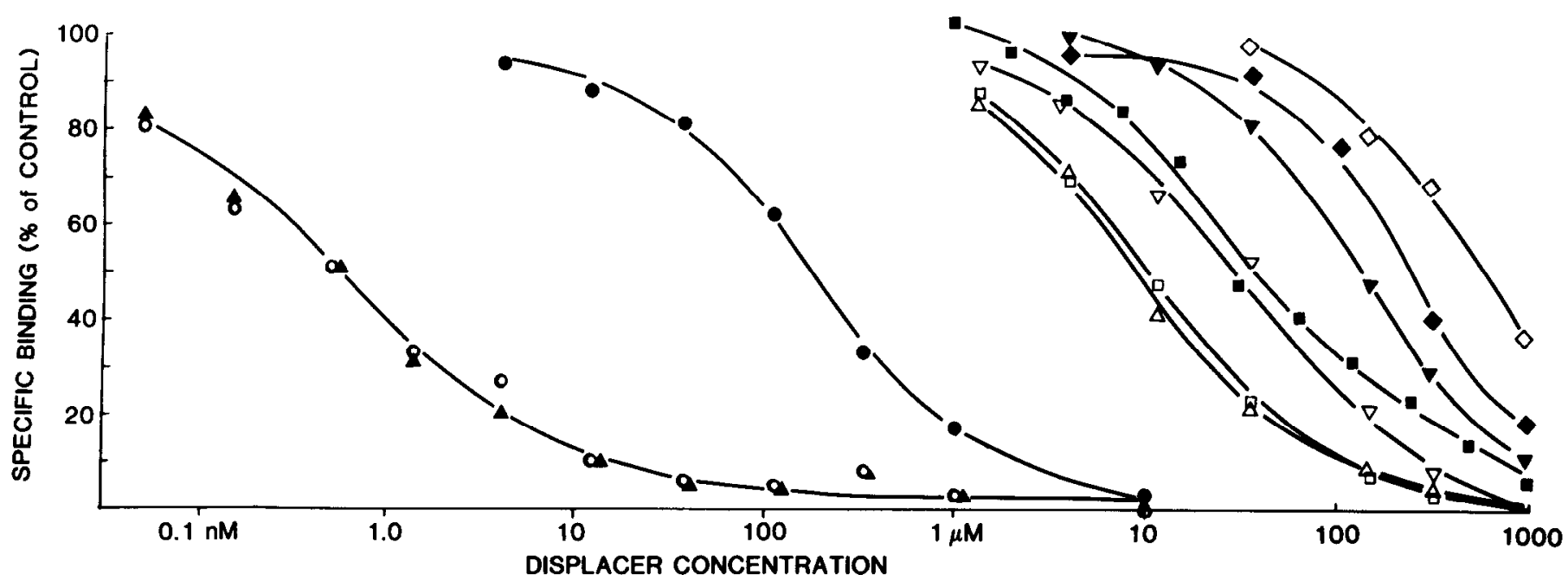

Figure 3. Displacement of $\left[{ }^{3} \mathrm{H}\right] \mathrm{NBI}$ binding to membranes from rat brain by adenosine analogues and adenosine uptake inhibitors. $\mid \mathrm{C}_{50}$ values for $\mathrm{NBI}$ $(\Delta)$, NBG $(\mathcal{O})$, dipyridamole $(\bullet), \mathrm{CHA}(\Delta),(+)$-PIA $(\square),(-)$-PIA $(\nabla)$, papaverine $(\square)$, 2-chloroadenosine $(\nabla), 2^{\prime}$-deoxyadenosine $(\bullet)$ and NECA $(\diamond)$ were determined using $0.6 \mathrm{nM}\left[{ }^{3} \mathrm{H}\right] \mathrm{NBI}$ and 8 to 10 concentrations of the displacers. Control binding represents that amount of $\left[{ }^{3} \mathrm{H}\right] \mathrm{NBI}$ binding displaceable by 5 $\mu \mathrm{M} \mathrm{NBI}$. These results are representative of experiments performed in duplicate and conducted at least twice with similar results. 
287 to $340 \mu \mathrm{M}$ for uridine, cytidine, guanosine, and inosine (Bender et al., 1981). These findings in neuronal systems contrast with those reported for other tissues. In cultured Novikoff and P388 cells, for example, the $K_{m}$ values for adenosine transport were 103 and 123 $\mu \mathrm{M}$, respectively, whereas those for inosine, thymidine, and uridine ranged from 125 to $250 \mu \mathrm{M}$ (see Plagemann and Wohlhueter, 1980). Thus, it may be concluded that a high affinity ( 1 to $10 \mu \mathrm{M}$ ) adenosine transporter exists on neurons, whereas a lower affinity (100 to 1000 $\mu \mathrm{M})$ system having broader substrate specificity is associated with glial cells (Thampy and Barnes, 1983a) and peripheral tissues.

The present results support the contention that $\left[{ }^{3} \mathrm{H}\right] \mathrm{NBI}$ binds to transport sites in brain which do not have a broad substrate specificity and are active at concentrations of adenosine (about $2.0 \mu \mathrm{M}$ ) normally found in brain (Winn et al., 1979; Zetterstrom et al., 1982). There are two possible explanations for the apparent differences in nucleoside specificity between neuronal and non-neuronal tissues. The neuronal sites that bind $\left[{ }^{3} \mathrm{H}\right] \mathrm{NB}$ I may be fundamentally different from those found on other cell types. Alternatively, at least two populations of nucleoside transport sites may exist in both the periphery and the brain with high affinity $\left[{ }^{3} \mathrm{H}\right] \mathrm{NBI}$ sites in the brain being more abundant and having higher affinity and selectivity for adenosine. In either case, the neuronal adenosine uptake site labeled by $\left[{ }^{3} \mathrm{H}\right] \mathrm{NBI}$ may have a critical role in controlling extracellular adenosine levels, particularly at adenosine release sites. Thus, $\left[{ }^{3} \mathrm{H}\right] \mathrm{NB}$ may be a useful ligand for localizing neural systems in the CNS where adenosine exerts its physiological actions.

The degree of interaction of various adenosine receptor agonists and antagonists with $\left[{ }^{3} \mathrm{H}\right] \mathrm{NB}$ l binding sites was examined. The affinities of the adenosine receptor agonists $\mathrm{CHA}_{1}(+)$ - and (-)-PIA, 2-chloroadenosine, and NECA (Table I) for the [ $\left.{ }^{3} \mathrm{H}\right] \mathrm{NBI}$ binding site were approximately three orders of magnitude lower than their affinities for adenosine receptors in brain and spinal cord membrane preparations (Daly, 1982; Geiger et al., 1984b). Additionally, the rank order of potencies of these agonists for the $\left[{ }^{3} \mathrm{H}\right] \mathrm{NBI}$ site does not correspond with their affinities for the $A_{1}$-receptor where (-)-PIA > $\mathrm{CHA}>2$-chloroadenosine $>$ NECA $>(+)$-PIA. The interaction of $\left[{ }^{3} \mathrm{H}\right] \mathrm{NBI}$ with $\mathrm{A}_{2}$ adenosine receptors is also unlikely since, at this receptor, (+)- and (-)-PIA exhibit little, if any, stereoselectivity; in the present study $(+)$-PIA was found to have 3 -fold greater affinity than $(-)$-PIA for the $\left[{ }^{3} \mathrm{H}\right] \mathrm{NBI}$ site. The weak potency of NECA for displacing $\left[{ }^{3} \mathrm{H}\right] \mathrm{NBI}$ also tended to rule out an interaction with $A_{2}$ sites since NECA is reported to have nanomolar affinity for the $A_{2}$-receptor (Daly, 1982). The adenosine receptor antagonists caffeine, theophylline, and enprofylline, as well as adenine and guanine nucleotides, were all virtually without effect on $\left[{ }^{3} \mathrm{H}\right] \mathrm{NBI}$ binding at concentrations up to $1 \mathrm{~mm}$. The intracellular adenosine receptor, classified as the $P$ site, is known to have greater affinity for $2^{\prime}$-deoxyadenosine than for 2-chloroadenosine. However, 2-chloroadenosine was more potent than $2^{\prime}$-deoxyadenosine in displacing $\left[{ }^{3} \mathrm{H}\right] \mathrm{NBI}$, a finding inconsistent with $\left[{ }^{3} \mathrm{H}\right] \mathrm{NBI}$ interacting with this intraccllular site.

As shown in Figure 3 , adenosine analogues gave parallel displacement curves of $\left[{ }^{3} \mathrm{H}\right] \mathrm{NBI}$ binding, indicating their competition for similar sites on the membranes. These findings can be interpreted on the basis of structure-activity relationships. The potent inhibitory actions of $\mathrm{NBI}$ and related compounds have been attributed to the 6 substituted nitrobenzyl and 9-ribosyl moieties extending from the purine ring (Paterson and Oliver, 1971). CHA and (+)- and (-)-PIA are similar to NBI in that both have the 9-ribosyl group as well as hydrophobic ring structures at the $\mathrm{N}^{6}$-position. 2-Chloroadenosine and NECA were less potent in displacing $\left[{ }^{3} \mathrm{H}\right] \mathrm{NBI}$, possibly because of the absence of the $N^{6}$ group. Therefore, when considering the biological actions of these adenosine receptor agonists, inhibition of endogenous adenosine uptake may be a factor in contributing to their behavioral and electrophysiological effects.

\section{References}

Bender, A. S., P. H. Wu, and J. W. Phillis (1980) The characterization of $\left[{ }^{3} \mathrm{H}\right]$ adenosine uptake into rat cerebral cortical synaptosomes. J. Neurochem. 35: $629-640$.
Bender, A. S., P. H. Wu, and J. W. Phillis (1981) Some biochemical properties of the rapid adenosine uptake system in rat brain synaptosomes. J. Neurochem. 37: 1282-1290.

Cass, C. E., L. A. Gaudette, and A. R. P. Paterson (1974) Mediated transport of nucleosides in human erythrocytes. Specific binding of the inhibitor nitrobenzylthioinosine to nucleoside transport sites in the erythrocyte membrane. Biochim. Biophys. Acta 345: 1-10.

Cass, C. E., N. Kolassa, Y. Uehara, E. Dahlig-Harley, E. R. Harley, and A. R. P. Paterson (1981) Absence of binding sites for the transport inhibitor nitrobenzylthioinosine on nucleoside transport-deficient mouse lymphoma cells. Biochim. Biophys. Acta 649: 769-777.

Cheng, Y. C., and H. R. Prusoff (1973) Relationship between the inhibition constant $\left(K_{i}\right)$ and the concentrations of inhibitor which causes $50 \%$ inhibition $\left(\mathrm{IC}_{50}\right)$ of an enzymatic reaction. Biochem. Pharmacol. 22: 30993108.

Cornford, E. M., and W. H. Oldendorf (1975) Independent blood-brain barrier transport systems for nucleic acid precursors. Biochim. Biophys. Acta 394: 211-219.

Dahlig-Harley, E., Y. Eilam, A. R. P. Paterson, and C. E. Cass (1981) Binding of nitrobenzylthioinosine to high-affinity sites on the nucleoside-transport mechanism of the HeLa cells. Biochem. J. 200: 295-305.

Daly, J. W. (1982) Adenosine receptors: Targets for future drugs. J. Med. Chem. 25: 197-207.

Fonnum, F. (1984) Glutamate: A neurotransmitter in mammalian brairı. J. Neurochem. 42: 1-11.

Geiger, J. D., F. S. LaBella, and J. I. Nagy (1984a) Ontogenesis of adenosine receptors in the central nervous system of the rat. Dev. Brain Res. 13: 97104.

Geiger, J. D., F. S. LaBella, and J. I. Nagy (1984b) Characterization and localization of adenosine receptors in rat spinal cord. J. Neurosci. 4: 23032310.

Goodman, R. R., and S. H. Snyder (1982) Autoradiographic localization of adenosine receptors in rat brain using $\left[{ }^{3} \mathrm{H}\right]$ cyclohexyladenosine. J. Neurosci. 2: 1230-1241.

Goodman, R. R., M. J. Kuhar, L. Hester, and S. H. Snyder (1983) Adenosine receptors: Autoradiographic evidence for their location on axon terminals of excitatory neurons. Science 220: 967-969.

Hammond, J. R., and A. S. Clanachan (1983) Distribution of nucleoside transport sites in guinea-pig brain. J. Pharm. Pharmacol. 35: 117-118.

Hammond, J. R., and A. S. Clanachan (1984) [ $\left.{ }^{3} \mathrm{H}\right]$ Nitrobenzylthioinosine binding to the guinea pig CNS nucleoside transport system: A pharmacological characterization. J. Neurochem., in press.

Hertz, L. (1978) Kinetics of adenosine uptake into astrocytes. J. Neurochem. 31: $55-62$.

Jarvis, S. M., and J. D. Young (1982) Nucleoside translocation in sheep reticulocytes and fetal erythrocytes: A proposed model for the nucleoside transporter. J. Physiol. (Lond.) 324: 47-66.

Jarvis, S. M., D. McBride, and J. D. Young (1982) Erythrocyte nucleoside transport: A symmetrical binding of nitrobenzylthioinosine to nucleoside permeation sites. J. Physiol. (Lond.) 324: 31-46.

Langer, S. Z., C. Moret, R. Raisman, M. L. Dubocovich, and M. Briley (1980) High affinity $\left[{ }^{3} \mathrm{H}\right]$ imipramine binding in rat hypothalamus: Association with uptake of serotonin but not of norepinephrine. Science 210: 1133-1135.

Lee, C. M., J. A. Javitch, and S. S. Snyder (1982) Characterization of $\left[{ }^{3} \mathrm{H}\right]$ desipramine binding associated with neuronal norepinephrine uptake sites in rat brain membranes. J. Neurosci. 2: 1515-1525.

Lowry, O. H., N. J. Rosebrough, A. L. Farr, and R. J. Randall (1951) Protein measurement with the Folin phenol reagent. J. Biol. Chem. 193: 265-275.

Marangos, P. J., R. Clark-Rosenberg, and J. Patel (1982a) [ $\left.{ }^{3} \mathrm{H}\right]$ Nitrobenzylthioinosine is a photoaffinity probe for adenosine uptake sites in brain. Eur. J. Pharmacol. 85: 359-360.

Marangos, P. J., J. Patel, R. Clark-Rosenberg, and A. M. Martins (1982b) $\left[{ }^{3} \mathrm{H}\right]$ Nitrobenzylthioinosine binding as a probe for the study of adenosine uptake sites in brain. J. Neurochem. 39: 184-191.

Meunier, F. M. and N. Morel (1978) Adenosine uptake by cholinergic synaptosomes from Torpedo electric organ. J. Neurochem. 31: 845-851.

Munson, P. J., and D. Rodbard (1980) LIGAND: A versatile computerized approach for characterization of ligand-binding systems. Anal. Biochem. 107: 220-239.

Nagy, J. I., L. A. LaBella, and M. Buss (1984) Immunohistochemistry of adenosine deaminase: Implications for adenosine neurotransmission. Science 224: 166-168.

Paterson, A. R. P., and J. M. Oliver (1971) Nucleoside transport. II. Inhibition by $p$-nitrobenzylthioguanosine and related compounds. Can. J. Biochem. 49: $271-274$. 
Paterson, A. R. P., N. Kolassa, and C. E. Cass (1981) Transport of nucleoside drugs in animal cells. Pharmacol. Ther. 12: 515-536.

Phillis, J. W., and P. H. Wu (1981) The role of adenosine and its nucleotides in central synaptic transmission. Prog. Neurobiol. 16: 187-239.

Phillis, J. W. and P. H. Wu (1983) Nitrobenzylthioinosine inhibition of adenosine uptake in guinea-pig brain. J. Pharm. Pharmacol. 35: 540

Plagemann, P. G. W., and R. M. Wohlhueter (1980) Permeation of nucleosides, nucleic acid bases, and nucleotides in animal cells. Curr. Top. Membr. Transp. 14: 225-330.

Schubert, P., W. Komp, and G. W. Kreutzberg (1979) Correlation of 5'. nucleotidase activity and selective transneuronal transfer of adenosine in the hippocampus. Brain Res. 168: 419-424.

Shi, M. M., J. -S. R. Wu, C. -M. Lee, and J. D. Young (1984) Nucleoside transport. Photoaffinity labeling of high-affinity nitrobenzylthioinosine binding sites in rat and guinea pig lung. Biochem. Biophys. Res. Commun. 118: $594-600$.

Stone, T. W. (1981) Physiological roles for adenosine and adenosine $5^{\prime}$ triphosphate in the nervous system. Neuroscience 6: 523-555.

Thampy, K. G., and E. M. Barnes, Jr. (1983a) Adenosine transport by primary cultures of neurons from chick embryo brain. J. Neurochem. 40: 874-879.

Thampy, K. G., and E. M. Barnes, Jr. (1983b) Adenosine transport by cultured glial cells from chick embryo brain. Arch. Biochem. Biophys. 220: 340-346.

Williams, E. F., P. H. Barker, and A. S. Clanachan (1984) Nucleoside transport in heart: Species differences in nitrobenzylthioinosine binding, adenosine accumulation, and drug-induced potentiation of adenosine action. Can. J. Physiol. Pharmacol. 62: 31-37.

Winn, R. H., R. Rubio, and R. M. Berne (1979) Brain adenosine production, in the rat during 60 seconds of ischemia. Circ. Res. 45: 486-492.

Wohlhueter, R. M., R. Marz, and P. G. W. Plagemann (1979) Thymidine transport in cultured mammalian cells. Kinetic analysis, temperature dependence and specificity of the transport system. Biochim. Biophys. Acta 533: 262-283.

Wojcik, W. J., and N. H. Neff (1983) Differential location of adenosine $A_{1}$ and $A_{2}$ receptors in striatum. Neurosci. Lett. 41:55-60.

Wu, P. H., and J. W. Phillis (1982) Nucleoside transport in rat cerebral cortical synaptosomal membrane: A high affinity probe study. Int. J. Biochem. 14: 1101-1105.

Young, J. D., and S. M. Jarvis (1983) Nucleoside transport in animal cells. Biosci. Rep. 3: 309-322.

Zetterstrom, T., L. Vernet, U. Ungerstedt, U. Tossman, B. Jonzon, and B. B. Fredholm (1982) Purine levels in the intact rat brain. Studies with an implanted perfused Hollow fibre. Neurosci. Lett. 29: 111-115. 